надавало можливість безробітним не втратити кваліфікацію, та забезпечувало хоча б невеличку матеріальну підтримку.

\title{
Література:
}

1. О проверке, экспертизе и практическом испытании профессиональной подготовки ищущих труда: Инструкция Наркомтруда СССР № 28. Известия НКТ УССР. 1923. № 3/27. С. 53-56.

2. Тимчасове положення про колективи безробітних від 23 травня 1925 p. ЗУ УСРР. 1925. № 27. Ст. 217.

DOI https://doi.org/10.30525/978-9934-588-92-1-16

\section{ОСОБЛИВОСТІ СТАНОВЛЕННЯ ЗАКОНОДАВСТВА ЗА ДОБИ ЗАХІДНО-УКРАЇНСЬКОЇ НАРОДНОЇ РЕСПУБЛІКИ У НАУКОВОМУ ДОРОБКУ М. ЧУБАТОГО ТА М. ЛОЗИНСЬКОГО}

\author{
Чубата М. В. \\ кандидат юридичних наук, \\ доиент кафедри теорії та історії права та держави \\ Інституту права
}

Київського національного університету імені Тараса Шевченка м. Київ, Украӥна

Законодавчим та державотворчим процесам в ЗУНР одним з перших серед дослідників-правознавців присвятив серію своїх публікацій Микола Чубатий $[1 ; 2 ; 3]$. Як високий урядовець і активний учасник визвольних змагань в ЗУНР, М. Чубатий мав нагоду наочно спостерігати за розбудовою та стабілізацією державного ладу. Особливий інтерес викликає п'ятий підрозділ його книги, названий «Законодавча влада» [2, с. 1-15]. Оцінюючи процеси державного будівництва в ЗУНР, автор наголошував: «Треба собі признати, що на загал велике діло державного будівництва сповнили ми надсподівано успішно» [2, с. 4]. На жаль, у цій праці дослідник не виокремлює конституційне законодавство як самостійний аспект. Дещо пізніше М. Чубатий продовжив дослідження цієї проблематики в грунтовній статті [3, с. 3-12], в якій виокремлює два підрозділи, що стосувалися безпосередньо законодавства ЗУНР: «Історично-правні основи Західньо-Української Республіки» та «Історично-правні основи акту 
соборности українських земель 22 січня 1919 р.». У першому з них зазначалося, що «утворення Західньо-Української Держави було на ділі відокремленням «Королівства Галичини та Володимирії» в окрему одиницю», ... а «революційний акт Першого Листопаду 1918 р. не був актом утворення Західньо-Української Держави, а актом фактичного захоплення влади від австрійських адміністраційних органів» [3, с. 10-11]. Щодо історично-правних основ акту Злуки, то на думку М. Чубатого, «акт соборности України з 22 січня 1919 р. був проведений вже державно-правними актами легально-існуючих органів обидвох республік» та аналізує ці чотири акти: 1) Фастівську угоду від 1 грудня 1918 р.; 2) Постанову УНРади від 3 січня 1919 р.; 3) Рішення Директорії, яким прийнято постанову УНРади ЗУНР про злуку обох республік; 4) Постанову Трудового Конгресу, як спільного парламенту обох колишніх самостійних республік, яка затверджувала всі дотеперішні акти в цій справі та проголошувала нову об'єднану Українську Народну Республіку як суверенну державу українського народу [3, с. 12].

Значно більше різних аспектів проблеми виокремив та дослідив у своїй монографії М. Лозинський [4]. Характеризуючи процеси державного будівництва в ЗУНР, дослідник активно застосовує синонімічні терміни «організація державного життя» та «будування держави». Особливий інтерес викликає II частина книги, названа «ЗахідноУкраїнська Народня Республіка». Аналіз законодавства дослідник почав 3 двох відозв УНРади до населення м. Львова та до всього українського народу, якими, як зазначає М. Лозинський, було офіційно оголошено про взяття державної влади у Львові і в цілій новоутвореній українській державі [4, с. 42].

Першим законом, який ухвалила УНРада, автор називає «Тимчасовий основний закон...» від 13 листопада 1918 р., подає його текст, правда $з$ купюрами (про це детально подано матеріал в нашій попередній публікації [5, с. 48-51]), та коментує, чому його треба оцінювати як тимчасовий: «містить він тільки постанови, найконечніші для законного ствердження державної самостійности українських земель бувшої Австро-Угорщини» [4, с. 45-46]. Продовжив М. Лозинський аналіз законодавства стислою характеристикою законів «Про тимчасову адміністрацію областей ЗУНР» та «Про тимчасову організацію судів і власти судейської», підкресливши важливість, нагальність і своєчасність їх прийняття [4, с. 46-47].

Наступну групу законодавчих актів, стисло проаналізованих автором, склали ті, що були ухвалені УНРадою після іiі переїзду до Станіславова. Першим таким актом стала постанова від 3 січня 1919 р. 
про злуку ЗУНР з УНР. Із законів про організацію державної влади, ухвалених УНРадою на початку 1919 року, дослідник найважливішим називає «Про Виділ Української Національної Ради», яким було утворено установу, що мала виконувати владу глави держави, а також коментує закон, що доповнював статут УНРади, на основі якого президентом УНРади вибрано Є.Петрушевича [4, с. 62-63].

3 метою комплексного аналізу законодавчих актів, що стосувались соборності України, М. Лозинський виокремлює для їх характеристики спеціальний розділ під назвою «З'єднання ЗУНР з УНР» [4, с. 67-73], а завершує аналіз законодавства про державне будівництво в ЗУНР розділом «Остання сесія Української Національної Ради» [4, с. 85-95]. Дослідник зазначає, що ця сесія розпочалася 25 березня, а закінчилась 15 квітня 1919 р. та стисло аналізує найважливіші закони цього періоду, ухвалені УНРадою, зокрема: про громадянство; про 8-ми годинний робочий день; земельний закон; про вибори до сойму; про скликання сойму. Особливу увагу М. Лозинським приділено двом останнім законам, які стосувалися Сойму ЗОУНР, який після запланованих на червень 1919 р. виборів, повинен був стати новим законодавчим органом, замість УНРади, наголошуючи, що УНРада була тимчасовим законодавчим органом, а Сойм ЗОУНР утворювався як постійний законодавчий орган [4, с. 90-91]. Автор констатує, що, на жаль, судилося інакше: «Ця сесія Української Національної Ради була остання, бо територія Західної Області Української Народньої Республіки впала жертвою польського наїзду» [4, с. 95]. Отже, військові події унеможливили не лише скликання та діяльність Сойму ЗОУНР, а й проведення самих виборів.

Значний інтерес для істориків права являє собою видання Президії Української Національної Ради «За державну незалежність Галичини», підготовлене М. Лозинським [6], де стисло викладена законотворча та державотворча діяльність ЗУНР. На жаль, ця публікація $є$ маловідомою, не використовується сучасними дослідниками, які звертаються до більш новішої і популярної праці М. Лозинського (Галичина в рр. 1918-1920. Відень, 1922), стисло проаналізованої нами вище. Проте, саме у виданні УНРади, підготовленому М. Лозинським у 1921 р., окремим додатком вперше оприлюднено законопроект «Основи державного устрою Галицької Республіки», вироблений урядом ЗУНР і запропонований Найвищій Раді і Лізі Націй 30 квітня 1921 p. [6, с. 1-10]. Слід зазначити, що в документі ніде немає навіть згадки про ЗУНР чи ЗОУНР, а з'являється новий термін назви майбутньої держави «Галицька Республіка», до речі, і сам 
М. Лозинський нехтує назвами ЗУНР-ЗОУНР, а зазначає, що документ підготовлений УНРадою Східної Галичини [6, с. 43].

Як бачимо, М. Лозинський своїми працями еміграційного періоду вніс значний вклад в розробку досліджуваної нами проблеми, проте варто зауважити, що цю дослідницьку діяльність вчений продовжив і в серії своїх публікацій радянського періоду, про що мова піде нижче.

За радянської доби з відомих і вже висвітлених в історіографії причин, ця проблема науковцями грунтовно не досліджувалась, проте окремі іiі аспекти все ж знайшли своє фрагментарне відображення в літературі, яку, на наш погляд, варто розділити на 1) політико-пропагандистську [7], в якій визнавався факт існування національної державності в Україні, але весь аналіз діяльності іiі органів, у тому числі й в сфері законодавства, зводився до характеристики «буржуазно-націоналістичної» й «антинародної» сутності цієї діяльності, і 2) власне наукові публікації. Щодо останніх, то тут варто згадати серію статей М. Лозинського радянського періоду, виданих після його повернення з еміграції в Україну [8; 9; 10], в яких він узагальнює досвід галицької революції. Аналізуючи законодавчі процеси в ЗУНР, дослідник здійснює стислу класифікацію законодавства, виокремлюючи групу «державно-творчих актів» УНРади: «1) маніфест 3 18 жовтня 1918 р. про утворення західно-української держави; 2) тимчасовий основний закон від 13 листопада 1918 р.; 3) акт про сполуку ЗУНР з УНР з 3 січня 1919 р.» [8, с.1089]. М. Лозинський виокремлює також кілька етапів в законодавчій діяльності УНРади: до 3 січня 1919 р.; 3 січня до березня 1919 р.; з березня до квітня 1919 р. та аналізує найважливіші законодавчі акти кожного з цих етапів [9]. Завершується дослідження прогностичним висновком автора, що «Галицька революція це був перший і початковий етап, який жде свого завершення» [9, с. 191]. На жаль, це були останні публікації М. Лозинського з державотворчої та законодавчої проблематики ЗУНР, в яких автор ще мав можливість вільного та об'єктивного висвітлення подій минулого. На цю проблематику на початку 1930-х років більшовиками було накладено табу.

\section{Лiтература:}

1. Чубатий М. Державний лад на Західній області Української Народної Республіки. На ріках Вавилонських: Літ.-політ. $і$ громад. альманах. Львів: Видання Товариства «Просвіта», 1920. Ч. 4. С. 96-133.

2. Чубатий М. Державний лад на Західній області Української Народної Республіки. Львів, 1921. 40 с.

3. Чубатий М. Історично-правні основи актів самостійности та соборности України 1918 і 1919 рр. Правничий вісник. Нью-Йорк, 1963. Кн. 2. С 3-12. 
4. Лозинський М. Галичина в рр. 1918-1920. Відень, 1922. 228 с.

5. Чубата М. Конституційне законодавство ЗУНР: до питання про автентичні та неавтентичні тексти «Тимчасового Основного закону» від 13 листопада 1918 р. Часопис Київського університету права. 2014. Вип. 3. С. 48-51.

6. За державну незалежність Галичини. Чому українська Галичина не може прийти під Польщу. Зладив д-р М. Лозинський. Відень, 1921. $43 \mathrm{c}$.

7. Бош Е. Национальное правительство и Советская власть в Украине. М.: Книгоизд-во «Коммунист», 1919. 56 с.; Майоров М. Из истории революционной борьбы на Украине (1914-1919). К. : Держвидав, 1922. 108 с.

8. Лозинський М. В десятиріччя галицької революції: (Галичина, Антанта й Рад. Союз). Червоне право. Х., 1928. № 23. С. 1089-1098.

9. Лозинський М. В десятиріччя галицької революції: Факти й спроба оцінки. Червоний шлях. Х.,1928. № 11. С.180-191.

10. Лозинський М. Річниця уярмлення Галичини. Червоний шлях. 1928. № 3. С. 91-102.

DOI https://doi.org/10.30525/978-9934-588-92-1-17

\section{УНІФІКАЦІЯ ДЕРЖАВНОГО АПАРАТУ ТА ПРАВА УКРАЇНИ-ГЕТЬМАНЩИНИ ЯК ЗАСІБ ЛІКВІДАЦЇ̈ ÏÏ АВТОНОМІЇ: ІСТОРИКО-ПРАВОВА РОЗВІДКА}

Шевченко О. В.

аспірант

Харківського національного університету імені В. Н. Каразіна м. Харків, Україна

Традиційно процеси ліквідації Гетьманщини, уніфікації ії державного апарату та права із загальноросійськими у вітчизняній та зарубіжній історіографії пов'язують $з$ добою правління Катерини II. Саме 3 набуттям нею влади, як зазначає В. М. Горобець, «взаємини українського Гетьманату та російського самодержавства набули якісно нового звучання». Саме тоді розпочинається абсолютно новий та, як виявилося пізніше, завершальний етап їхнього розвитку, «коли українська сторона була представлена власною ранньоновою державною організацією та, 